\title{
Green Synthesis, Characterization and Cholinesterase Inhibitory Potential of Gold Nanoparticles
}

\author{
Zainab $^{1}$, Khalid Saeed ${ }^{2}$, Ammara $^{1}$, Shujaat Ahmad ${ }^{3}$, Hanif Ahmad ${ }^{1}$, Farhat Ullah ${ }^{4}$, Abdul Sadiq ${ }^{4}$ \\ Ala Uddin ${ }^{2}$, Idrees Khan ${ }^{2 *}$, Manzoor Ahmad ${ }^{1 *}$ \\ ${ }^{1}$ Department of Chemistry, University of Malakand, Chakdara, Dir (L), Khyber Pakhtunkhwa, Pakistan. \\ ${ }^{2}$ Department of Chemistry, Bacha Khan University, Charsada, Khyber Pakhtunkhwa, Pakistan. \\ ${ }^{3}$ Department of Pharmacy, Shaheed Benazir Bhutto University, Sheringal, KPK, Pakistan. \\ ${ }^{4}$ Department of Pharmacy, University of Malakand, Chakdara, Dir (L), Khyber Pakhtunkhwa, Pakistan.
}

*Corresponding author: Idrees Khan, e-mail: idreeschem_uom@yahoo.com

Received December $6^{\text {th }}, 2020$; Accepted May 13 ${ }^{\text {th }}, 2021$.

DOI: http://dx.doi.org/10.29356/jmcs.v65i3.1479

\begin{abstract}
The green synthesis of gold nanoparticles (Au NPs) from their precursor was carried out using Delphinium uncinatum and Erythrophyleum guineense plants extracts. The Au NPs obtained were characterized by various instrumental techniques such as scanning electron microscopy (SEM), energy dispersive X-ray (EDX), X-ray diffraction (XRD) and UV/Visible (UV/VIS) spectrophotometer. The SEM study presented that E. guineense (GE) and D. uncinatum (GN) synthesized gold nanoparticles was below 100 and $300 \mathrm{~nm}$, respectively. The micrographs also presented that E. guineense (GE) synthesized gold particles had irregular round shaped while the $D$. uncinatum $(\mathrm{GN})$ synthesized nanoparticles had cylindrical shaped. The XRD spectra presented peaks at about $38.1^{\circ}, 44.43^{\circ}, 64.6^{\circ}$ and $77.64^{\circ}$ can be indexed to (111), (200), (220) and (311) orientation, respectively, which confirmed the presence of gold nanoparticles. It means that both E. guineense (GE) and D. uncinatum (GN) synthesized gold nanoparticles are highly crystalline. The UV/VIS analysis presented that both plant extracts significantly reduced the gold slat and as a result high quantity of gold nanoparticles were formed. The E. guanense gold NP and D. uncinatum gold NPs were investigated for their in-vitro cholinesterases inhibitory potentials in $62.5-1000 \mu \mathrm{g} / \mathrm{mL}$ concentrations range. The bioactivity results presented that the loading of the test samples in gold NPs enhanced their AChE and BChE inhibitory potentials. Keywords: Green synthesis; morphology; gold nanoparticles; enzyme inhibition; bioactivity.
\end{abstract}

Resumen. La síntesis verde de nanopartículas de oro (NP de Au) se llevó a cabo mediante extractos de plantas de Delphinium uncinatum y Erythrophyleum guineense. Las NP de Au obtenidas se caracterizaron mediante diversas técnicas instrumentales como microscopía electrónica de barrido (SEM), dispersión de energía de rayos $\mathrm{X}(\mathrm{EDX})$, difracción de rayos X (XRD) y espectrofotómetro UV / Visible (UV / Vis). El estudio SEM reveló tamaños de las nanopartículas de oro sintetizadas por E. guineense (GE) y D. uncinatum (GN) por debajo de 100 y $300 \mathrm{~nm}$, respectivamente. Las micrografías también mostraron que las partículas de oro sintetizadas por E. guineense $(\mathrm{GE})$ tenían una forma redonda irregular, mientras que las nanopartículas sintetizadas por D. uncinatum (GN) tenían una forma cilíndrica. Los patrones XRD presentaron picos a aproximadamente $38.1^{\circ}$, $44.43^{\circ}, 64.6^{\circ}$ y $77.64^{\circ}$ pueden indexarse a la orientación (111), (200), (220) y (311), respectivamente, lo que confirmó la presencia de nanopartículas de oro cristalinas. El análisis UV / Vis mostró que ambos extractos de plantas formaron nanopartículas de oro. Se investigaron las NP de oro como inhibidores de colinesterasas in vitro en un intervalo de concentraciones de 62.5 a $1000 \mu \mathrm{g} / \mathrm{ml}$. Los resultados de la bioactividad mostraron que la carga de las muestras de prueba en NP de oro mejoró sus potenciales inhibidores de AChE y BChE. 
Palabras clave: Síntesis verde; morfología; nanopartículas de oro; inhibición de enzimas; bioactividad.

\section{Introduction}

The synthesis of nanoparticles has received exceptional attention due to their superior surface area to volume ratio, modified structure and more activity rather than macro molecules [1].The nanoparticles and nanomaterials have wide range of applications in various fields like health care, drug-gene delivery, cosmetics, energy science, catalysis, food and feed, environment, mechanics, optics, chemical industries, space industries, light emitters, electronics, optical devices, single electron transistors, nonlinear and photo-electrochemical applications. These applications depend on their completely new or superior properties such as size, distribution, and morphology [2]. The nanomaterials or particles are synthesized by various approaches like flame spray pyrolysis [3], sonochemical methods [4], chemical reduction [5], sol-gel methods [6] etc. The disadvantages of these techniques are the intensive use of solvents and synthetic reactants, which is harmful for the environment. For this reason, it is very desirable to develop alternative processes for synthesis of nanoparticles, which do not use toxic chemicals and more possible to be environmentally friendly. The biological methods for the synthesis of nanoparticles via microorganisms, enzymes, and plants or plant extracts have been suggested as possible eco-friendly alternatives to chemical and physical methods [7]. The microbial enzymes or plant phytochemcals have reducing or antioxidant properties, which are responsible for the reduction of metals to the corresponding nanoparticles [8-11]. Extensive research is gonging on green synthesis of nanoparticles from their corresponding salts. For example, Suganya et al [12] synthesized silver nanoparticles using Murrayakoenigii leaf extract against Anopheles stephensi and Aedes aegypti. Song et al [13] used leaf extract of Diopyros kaki as a reducing agent for the synthesis of platinum nanoparticles from an aqueous solution of $\mathrm{H}_{2} \mathrm{PtCl}_{6} \cdot 6 \mathrm{H}_{2} \mathrm{O}$. Rajasekharreddy et al [14] used the leaves of various plants like Tridax procumbens L. (Coat buttons), Jatropacurcas L. (Barbados nut), Calotropis gigantea L. (Calotropis), Solanum melongena L. (Eggplant), Datura metel L. (Datura), Carica papaya L. (Papaya) and Citrus aurantium L. (Bitter orange) for synthesis of silver and gold nanoparticles (Au NPs) from their precursor.

In the present study, the Au NPs were prepared by green synthesis, where the plant extracts of $D$. uncinatum and E. guineense were used as a reducing agent. Green synthesized Au NPs are reported for antibacterial [15, 16], antioxidant [17], anticancer [18] etc. but to the best of our knowledge it is not used in Alzeimer disease. The Au NPs were characterized by SEM, EDX, UV/VIS and XRD. The enzyme inhibition activities (acetylcholinesterase (AChE) of the gold nanoparticles were investigated.

\section{Experimental}

\section{Materials and methods Materials}

Methanol commercial grade (purity about $98 \%$ ) and Gold chloride salt was purchased from Sigma Aldrich.

\section{Samples collections and preparation}

The aerial parts of D. uncinatum (2 Kg dry wt) were collected from their natural habitat in May, 2014 and identified by Dr. Zahid Ullah, Assistant Professor, Institute of Plant Sciences, University of Swat, Khyber Pakhtunkhwa, Pakistan. The voucher specimen (UD.UOS-013) is deposited in the herbarium of the Institute. While E. guineense were collected from their natural habitat in 2006 and were identified by Dr. Mehboob Ur Rehman, Professor, Department of Botany, Jehanzeb Post Graduate College, Swat, Khyber Pakhtunkhwa, Pakistan. N The voucher specimen (EG016) is deposited in the herbarium of the Department Botany, Jehanzeb Post Graduate College, Saidu Sharif Swat. 
The aerial parts of both plants materials were chopped and grinded. Then the powdered plant materials were soaked in $80 \%$ commercial grade methanol for extraction (3 times each for 10 days). The obtained extracted materials were used to synthesize gold nanoparticles.

\section{Synthesis of gold nanoparticles}

The plant extract solution ( 0.3 percent) was prepared with deionized water and the solution was then filtered in order to remove any suspended materials. The clear solution of plant extract and gold chloride solution $(0.001 \mathrm{M})$ were taken in the rations of 3:7, respectively. The prepared solution was taken in $250 \mathrm{~mL}$ conical flask and magnetically stirred for $1.5 \mathrm{~h}$ at $80^{\circ} \mathrm{C}$. After the specific reaction time, the solution was cooled and gold NPs were separated by centrifugation $\left(15500 \mathrm{rpm}\right.$ at $\left.10^{\circ} \mathrm{C}\right)$. The synthesized gold nanoparticles were then dried in the oven at $100^{\circ} \mathrm{C}$.

\section{Characterization of gold Nanoparticles}

The morphological study of synthesized gold nanoparticles was carried out by JEOL, JSM-5910 SEM (high vacuum mode). The EDX analyses of gold nanoparticles were performed on EDX (Model INCA 200/Oxford Instruments, UK, company oxford). The UV/VIS study of gold nanoparticles in solution form was performed using UV-VIS spectrophotometer (UV-1800, Shimadzu, Japan).

\section{Results and discussion}

\section{Morphological study}

The SEM is one of the most important tools for the studying of size, shape of nanomaterials, and dispersion/agglomeration of nanomaterials in different matrixes. The SEM micrographs of gold nanoparticles are shown in Fig. 1. The micrographs presented that the E. guineense (GE) synthesized gold nanoparticles are present in the agglomerated with an irregular shape. The size of E. guineense (GE) synthesized gold nanoparticles was below $100 \mathrm{~nm}$. The SEM image of D. uncinatum (GN) synthesized gold particles was present in the form of cylindrical shaped. The size of cylindrical gold particles was below $300 \mathrm{~nm}$. The difference in shapes of gold particles obtained by two different plants extracts are might be due to the different chemical compounds in the plants extracts.
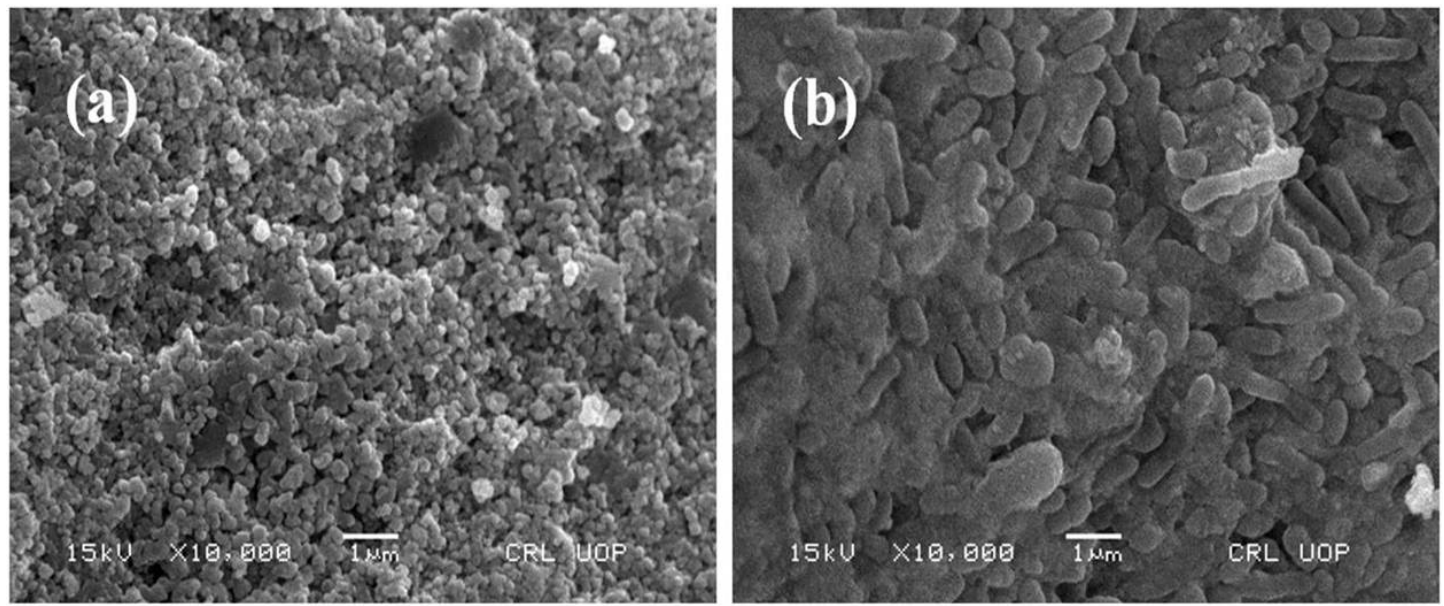

Fig. 1. SEM micrographs of (a) E. guineense and (b) D. uncinatum extracted gold nanoparticles.

Fig. 2 show the EDX spectra of E. guineense (GE) and D. uncinatum (GN) synthesized gold nanoparticles. The EDX results also presented that gold nanoparticles are synthesized by both types of extracts. 
The spectra illustrated that carbon, oxygen, copper and trace amount of chlorine is also present along with gold nanoparticles, which might be came from plants extract, solvent medium and the precursor salt.

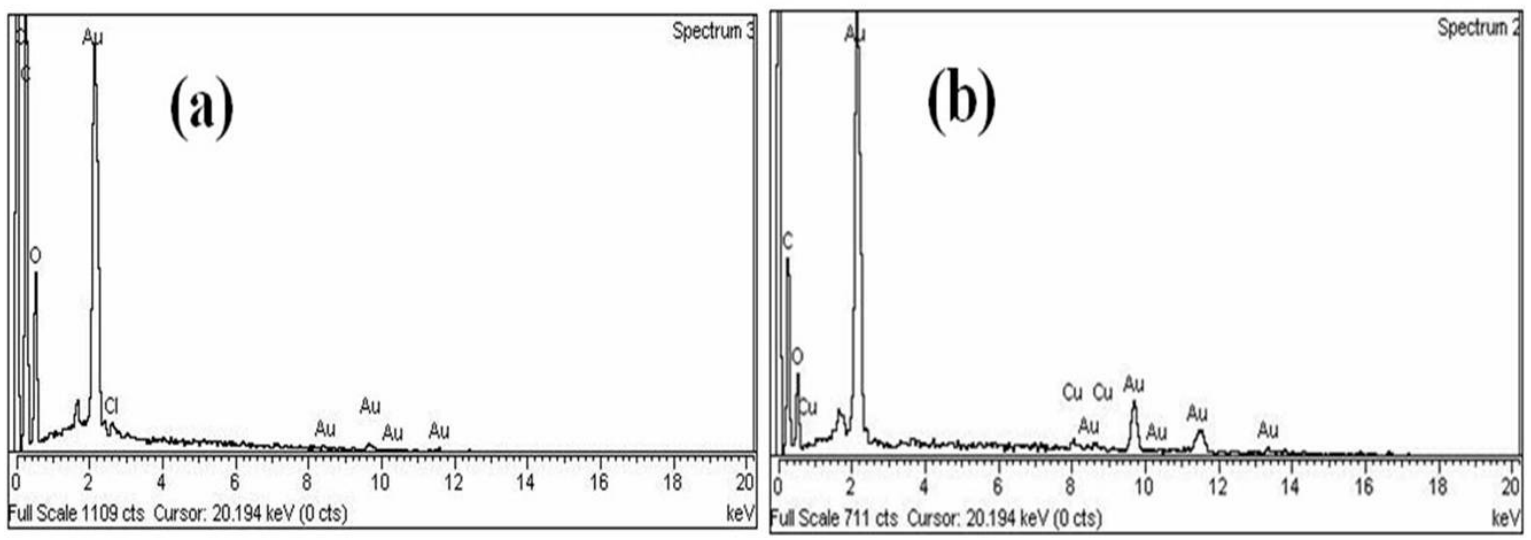

Fig. 2. EDX spectra of (a) E. guineense and (b) D. uncinatum extracted gold nanoparticles.

\section{UV/VIS study}

The confirmation of gold nanoparticles was also carried by out UV/VIS spectroscopy. Fig. 3 shows the UV/VIS spectra of E. guineense and D. uncinatum extracted gold nanoparticles, which gives broad peak at about $560 \mathrm{~nm}$. The appearance of peak clearly show that both plant extracts significantly reduced the gold salt and as a result high quantity of gold nanoparticles formation occurred. Similarly, Singh and Srivastava also reported almost similar UV/VIS spectra for gold nanoparticles where they used black cardamom extract for the synthesis of gold nanoparticles from their precursor [19]. The UV/VIS range observed in literature for green synthesized Au NPs are 579 to $535 \mathrm{~nm}[20]$.

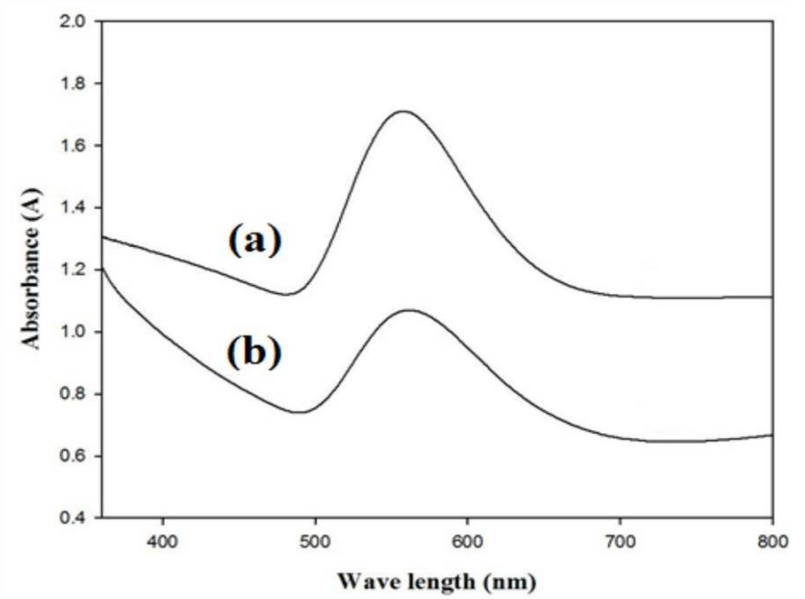

Fig. 3. UV/VIS spectra of (a) E. guineense and (b) D. uncinatum extracted gold nanoparticles.

\section{X-ray diffraction study}

In order to make sure the composition of gold nanoparticles, the synthesized nanoparticles were also analyzed by X-ray diffraction (XRD). Fig. 4 shows the X-ray diffraction (XRD) patterns of the green synthesized gold nanoparticles. The XRD spectra presented peaks at about $38.1^{\circ}, 44.43^{\circ}, 64.6^{\circ}$ and $77.64^{\circ}$ can be indexed to (111), (200), (220) and (311) orientation, respectively, which confirmed the face-centered cubic 
structure of $\mathrm{Au}$ NPs corresponding with ICDD PDF card number 00-004-0784. It means that the gold nanoparticles had cubic structure. The results also illustrate that both E. guineense (GE) and D. uncinatum (GN) synthesized gold nanoparticles are highly crystalline [21-24].

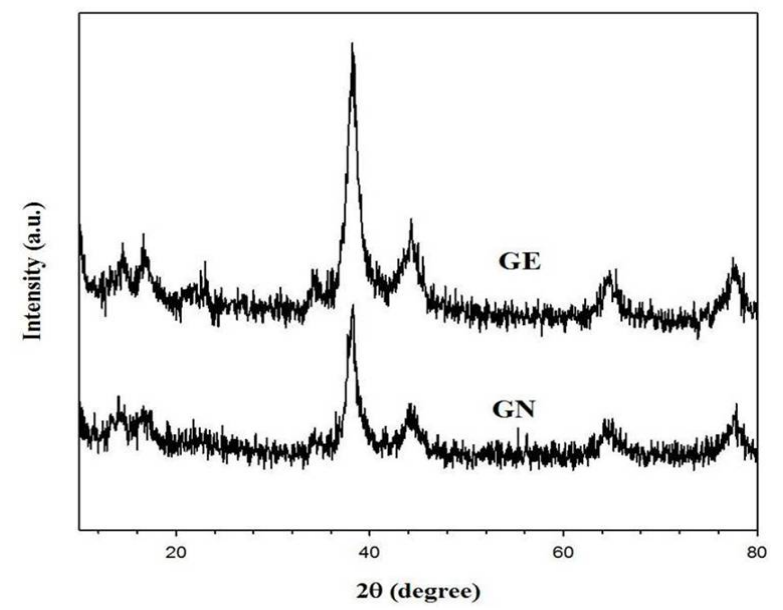

Fig. 4. XRD patterns of (a) E. guineense and (b) D. uncinatum extracted gold nanoparticles.

\section{Bioactivity of gold nanoparticles}

Alzheimer's disease (AD) is a an age related neurodegenerative disorder with clinical characteristic and pathological features associated with loss of neurons in certain brain areas leading to impairment of memory, cognitive dysfunction, behavioral disturbances, deficits in activities of daily living, which eventually leads to death $[25,26]$. In 2010 , approximately 35 million people worldwide were suffering from AD and this number is believed to reach 65.7 million by 2030 [27]. The cholinergic system is the most dramatically affected in $\mathrm{AD}$ due to remarkable depletion of acetylcholine $(\mathrm{ACh})$ levels. One of the rational and effective approaches to treat the AD's symptoms is raising the ACh through inhibition of acetyl cholinesterase (AChE) that is responsible for hydrolysis of Ach. Furthermore, butyrylcholinesterase (BuChE) also seems to be involved in the hydrolysis of ACh during the last stages of the disease. Moreover, $\mathrm{AChE}$ and $\mathrm{BuChE}$ have been found to be responsible for upregulating the expression of the amyloid precursor protein (APP). Thereby dual inhibition of $\mathrm{AChE}$ and $\mathrm{BuChE}$ could be effective in the management of $\mathrm{AD}$ symptoms as it would result in the increase of ACh synaptic levels and the decrease of neurotoxic A $\beta$ fibrils [28, 29].Commercially available synthetic drugs used for management of $\mathrm{AD}$ have been associated with drawbacks like gastrointestinal disturbances, moderate effectiveness, high cost and short half-life [30]. Natural product-based compounds have been increasingly explored for better effects. Desirable properties of botanical extracts or natural product-based compounds include a comparatively better penetration of the blood-brain barrier better than the pharmaceutical options and better specificity for human cholinesterase's [31].

Synthesis of metal nanoparticles (NPs) with a particular shape, size and morphology is an important area of modern research. These NPs are extensively used as an alternative strategy for both therapeutic and diagnostic purposes due to their unusual physical, chemical, electronic and biological properties. Biologically synthesized NPs using various biological sources such as plants tissues or extracts overcome several disadvantages over chemically synthesized NPs [32,33]. Metal NPs have attracted greater scientific interest for drug delivery applications. They offer unique advantages of enhancing the solubility and cross membrane transport of their surface tethered drugs [34]. Moreover, they are capable of delivering increased concentration of the loaded drugs to the target sites, thus elevated efficacy of the drugs achieved with minimal side effects on other normal tissues and cells [35].

Tables 1-2 shows the inhibitory potentials of E. guanense and D. uncinatum synthesized gold NPs. In current study, E. guanense gold NP and D. uncinatumgold NPs were investigated for their invitrocholinesterases inhibitory potentials in $62.5-1000 \mu \mathrm{g} / \mathrm{mL}$ concentrations range. All the tested samples 
revealed a concentration dependent inhibition of the target enzymes. Gold NPs of E. guanense revealed 67.02 $\pm 0.26 \%$ inhibition of $\mathrm{AChE}$ at the highest tested concentration of $1000 \mu \mathrm{g} / \mathrm{mL}$. When tested for BChE inhibition, they revealed $63.76 \pm 0.17 \%$ inhibition at $1000 \mu \mathrm{g} / \mathrm{mL}$. The results were quite comparable with standard drug galatamine exhibiting $76.65 \pm 0.43 \%$ and $72.38 \pm 0.33 \% \mathrm{AChE}$ and BChE inhibition respectively at $1000 \mu \mathrm{g} / \mathrm{mL}$ concentration.

Table 1. Anti-cholinesterase inhibitory activity of given samples galantamine used as standard.

\begin{tabular}{|c|c|c|c|c|c|}
\hline $\begin{array}{c}\text { Sample } \\
\text { name }\end{array}$ & Concentration $(\mu \mathrm{g} / \mathrm{mL})$ & $\begin{array}{c}\text { \% inhibition By } \\
\text { AChE, (mean } \pm \\
\text { SEM) }\end{array}$ & $\begin{array}{c}\text { IC50 } \\
(\mu \mathrm{g} / \mathrm{mL})\end{array}$ & $\begin{array}{c}\text { \% Inhibition by } \\
\text { BChE, (mean } \pm \\
\text { SEM) }\end{array}$ & $\begin{array}{c}\mathrm{IC}_{50} \\
(\mu \mathrm{g} / \mathrm{mL})\end{array}$ \\
\hline \multirow{5}{*}{$\begin{array}{l}\text { Gold NPs } \\
\text { (G.E) }\end{array}$} & 1000 & $67.02 \pm 0.26$ & \multirow{5}{*}{140} & $63.76 \pm 0.17$ & \multirow{5}{*}{210} \\
\hline & 500 & $62.69 \pm 0.41$ & & $57.61 \pm 2.21$ & \\
\hline & 250 & $55.08 \pm 0.22$ & & $51.51 \pm 0.70$ & \\
\hline & 125 & $48.77 \pm 1.12$ & & $44.51 \pm 0.04$ & \\
\hline & 62.5 & $42.99 \pm 0.08$ & & $38.39 \pm 0.16$ & \\
\hline \multirow{5}{*}{ Galantamine } & 1000 & $76.65 \pm 0.43$ & \multirow{5}{*}{42} & $72.38 \pm 0.33$ & \multirow{5}{*}{53} \\
\hline & 500 & $71.08 \pm 1.12$ & & $65.69 \pm 0.53$ & \\
\hline & 250 & $66.00 \pm 0.38$ & & $61.93 \pm 1.08$ & \\
\hline & 125 & $59.43 \pm 0.20$ & & $56.16 \pm 0.23$ & \\
\hline & 62.5 & $52.41 \pm 0.40$ & & $51.68 \pm 0.51$ & \\
\hline
\end{tabular}

SEM means Standard error mean, IC50 means half maximal inhibitory concentration.

D. uncinatumgold NPs showed $75 \%$ and $77 \%$ inhibition of AChE and BChE respectively at the highest tested concentration of $1000 \mu \mathrm{g} / \mathrm{mL}$. In comparison, standard drug galatamine showed $81 \%$ and $85 \%$ inhibition of $\mathrm{AChE}$ and $\mathrm{BChE}$ respectively at the highest tested concentration of $1000 \mu \mathrm{g} / \mathrm{mL}$.

Table 2. Anti-cholinesterase inhibitory potential of given compounds vial galantamine use as a standard.

\begin{tabular}{|c|c|c|c|c|c|}
\hline $\begin{array}{c}\text { Compound } \\
\text { name }\end{array}$ & $\begin{array}{c}\text { Concentration } \\
\mu \mathrm{g} / \mathrm{Ml}\end{array}$ & $\begin{array}{l}\text { \% AChE } \\
\text { inhibition }\end{array}$ & $I_{50} \mu \mathrm{g} / \mathrm{mL}$ & $\begin{array}{r}\% \mathrm{BChE} \\
\text { inhibition } \\
\end{array}$ & $\mathrm{IC}_{50} \mu \mathrm{g} / \mathrm{mL}$ \\
\hline \multirow{5}{*}{$\begin{array}{l}\text { Gold NPs } \\
\text { (GN) }\end{array}$} & 1000 & 75 & \multirow{5}{*}{89} & 77 & \multirow{5}{*}{45} \\
\hline & 500 & 67 & & 71 & \\
\hline & 250 & 62 & & 65 & \\
\hline & 125 & 55 & & 58 & \\
\hline & 62.5 & 47 & & 53 & \\
\hline \multirow{5}{*}{ Galantamine } & 1000 & 81 & \multirow{5}{*}{19} & 85 & \multirow{5}{*}{16} \\
\hline & 500 & 75 & & 79 & \\
\hline & 250 & 71 & & 71 & \\
\hline & 125 & 65 & & 67 & \\
\hline & 62.5 & 60 & & 62 & \\
\hline
\end{tabular}

The elevated inhibitory potentials of both the test samples can be linked to various factors. The loading of these test samples in NPs enhance their aqueous solubility, thus leading to their better in-vitro therapeutic efficacy. Moreover, the adsorption or interaction of these metal NPs on the cholinesterases proteins surfaces can also be linked to increased inhibitory potentials of these NPs as reported elsewhere [36]. The Au NPs (GE) was also utilized for the $\alpha$-Glucisidase inhibitory activity and the results are represented in the table 3 . 
Table 3. $\alpha$-Glucosidase inhibitory activity of given samples Acarbose used as standard.

\begin{tabular}{|c|c|c|c|}
\hline $\begin{array}{c}\text { Compound } \\
\text { name }\end{array}$ & $\begin{array}{c}\text { Concentration } \\
(\mu \mathrm{g} / \mathrm{mL})\end{array}$ & $\begin{array}{c}\alpha-\text { glucosidase } \% \text { inhibition } \\
(\text { mean } \pm \text { SEM })\end{array}$ & $\begin{array}{c}\mathrm{IC} \mathrm{C}_{50} \\
(\mu \mathrm{g} / \mathrm{mL})\end{array}$ \\
\hline \multirow{5}{*}{$\begin{array}{l}\text { Gold NPs } \\
\text { (G.E) }\end{array}$} & 1000 & $46.41 \pm 0.24$ & \multirow{5}{*}{1035} \\
\hline & 500 & $41.79 \pm 0.34$ & \\
\hline & 250 & $35.23 \pm 0.53$ & \\
\hline & 125 & $31.62 \pm 0.38$ & \\
\hline & 62 & $26.24 \pm 0.33$ & \\
\hline \multirow{5}{*}{ Acarbose } & 1000 & $70.35 \pm 0.49$ & \multirow{5}{*}{82} \\
\hline & 500 & $64.45 \pm 0.23$ & \\
\hline & 250 & $59.18 \pm 0.09$ & \\
\hline & 125 & $53.75 \pm 0.43$ & \\
\hline & 62.5 & $47.71 \pm 0.93$ & \\
\hline
\end{tabular}

\section{Conclusion}

The green synthesis of gold nanoparticles from their precursor was carried out by the plants extracts. The morphological study presented that E. guineense (GE) and D. uncinatum (GN) synthesized gold nanoparticles was below 100 and $300 \mathrm{~nm}$, respectively. The SEM images also presented that of E. guineense (GE) synthesized gold particles had irregular round shaped while the D. uncinatum (GN) synthesized nanoparticles had cylindrical shaped. The XRD analysis presented that the gold nanoparticles are highly crystalline. It was also found that the loading of the test samples in metal NPs enhanced their AChE and BChE inhibitory potentials. D. uncinatumgold NPs showed $75 \%$ and $77 \%$ inhibition of $\mathrm{AChE}$ and $\mathrm{BChE}$ respectively at the highest tested concentration of $1000 \mu \mathrm{g} / \mathrm{mL}$.

\section{Acknowledgments}

The authors are thankful to University of Malakand and Bacha Khan University for their supports.

\section{References}

1. Ghaffari-Moghaddam, M.; Hadi-Dabanlou, R.; Khajeh, M.; Rakhshanipour, M.; Shameli, K. Korean. J. Chem. Eng. 2014, 3, 548-557.

2. Ahmed, S.; Ahmad, M.; Swami, B.L.; Ikram, S. J. Adv. Res. 2016, 7, 17-28.

3. Grimm, S.; Schultz, M.; Barth, S.; Müller, R. J. Mater. Sci. 1997, 32, 1083-1092.

4. Kim, E.H.; Lee, H.S.; Kwak, B.K.; Kim, B.-K. J. Magn. Magn. Mater. 2005, 289, 328.

5. Saeed, K.; Khan, I.; Shah, T.; Park, S.-Y. FiberPolym. 2015, 16, 1870-1875.

6. Lemine, O.M.; Omri, K.; Zhang, B.; El Mir, L.; Sajieddine, M.; Alyamani, A.; Bououdina,M. Superlattices Microstruct. 2012, 52, 793-799.

7. Song, J.Y.; Kwon, E.-Y.; Kim , B.S. Bioprocess Biosyst. Eng. 2010, 33, 159-164.

8. Ahamd, A.; Mukherjee, P.; Mandal, D.; Senapati, S.; Khan, M.I.; Kumar, R.; Sastry, M. J Am. Chem. Soc. 2002, 12441, 12108-12109.

9. Jang, E.; Ryu, B.H.; Shim, H.W.; Ju, H.; Kim, D.W.; Kim, T.D. Int. J.Biol. Macromol. 2014, 65, 188192.

10. Lee, J.; Park, E.Y.; Lee, J. BioprocessBiosyst. Eng. 2014, 376, 983. 
11. Shukla, R.; SNune, N.K.; Chanda, N.; Katti, K.; Mekapothula, S.; Kulkarni, R.R.; Welshons, W.V.; Kannan, R.; Katti, K.V. Small. 2008, 4, 1425-1436.

12. Suganya, A.; Murugan, K.; Kovendan, K.; Kumar, P.M.; Hwang, J.-S. Parasitol Res. 2013, 112, $1385-$ 1397.

13. Song, J.Y.; Kwon, E.-Y.; Kim, B.S. Bioprocess Biosyst. Eng. 2010, 33, 159-164.

14. Rajasekharreddy, P.; Rani, P.U.; Sreedhar, B.. J. Nanopart. Res. 2010, 12, 1711.

15. Wang, L.; Natan, M.; Zheng, W.; Zheng, W.; Liu, S.; Jacobi, G.; Perelshtein, I.; Gedanken, A.; Banin, E.; Jiang, X. Nanoscale Adv. 2020, 2, 2293-2302.

16. Arief, S.; Nasution, F.W.; Zulhadjri; Labanni, A. J. Appl. Pharm. Sci. 2020, 10, 124-130.

17. Donga, S.; Bhadu, G.R.; Chanda, S. Artif. Cells, Nanomed., Biotechnol. 2020, 48, 1315-1325.

18. Botteon, C.E.A.; Silva, L.B.; Ccana-Ccapatinta, G.V.; Silva, T.S.; Ambrosio, S.R.; Veneziani, R.C.S.; Bastos, J.K.; Marcato, P.D. Sci. Rep. 2021, 11.

19. Singh, A.K.; Srivastava, O.N. Nanoscale. Res. Let. 2015, 10, 353.

20. ElMitwalli, O.S.;,Barakat, O.A.; Daoud, R.M.; Akhtar, S.; Henari, F.Z. J. Nanopart. Res. 2020, 22, 309.

21. State, R.; Papa, F.; Dobrescu, G.; Munteanu, C.; Atkinson, I.; Balint, I.; Volceanov, A. Environ. Eng. Manag. J. 2015, 14, 587-593.

22. Rajasekharreddy, P.; Rani, P.U.; Sreedhar, B. J Nanopart. Res. 2010, 12, 1711-1721.

23. Sett, A.; Gadewar, M.; Sharma, P.; Deka, M.; Bora, U. Adv. Nat. Sci.: Nanosci. Nanotechnol. 2016, 7 025005.

24. Doan, V.D.; Thieu, A.T.; Nguyen, T.D.; Nguyen, V.C.; Cao, X.T.; Nguyen, T.L.H.; Le, V.T. J. Nanomater. 2020, 2020.

25. Association AS.Alzheimer's disease facts and figures. Alzheimer's Dementia. 2012, 8, 131.

26. Jazayeri, S.B.; Amanlou, A.; Ghanadian, N.; Pasalar, P.; Amanlou, M. DARU J. Pharm. Sci. 2014, 22, 17.

27. International, ASD World Alzheimer report The global economic impact of dementia. Alzheimer's Dis. Int. 2010.

28. Penumala, M.; Zinka, R.B.; Shaik, J.B.; Gangaiah, D.A. BioMed. Res. Int. 2017, 1-12.

29. Schneider, J.A.; Arvanitakis, Z.; Bang, W.; Bennett, D.A. Neurology. 2007, 69, 2197-2204.

30. Owokotomo, I.A.; Ekundayo, O.; Abayomi, T.G.; Chukwuka, A.V. Toxicol. Rep. 2015, 2, 850-857.

31. Mukherjee, P.K.; Kumar, V.; Mal, M.; Houghton, P.J. Phytomedicine. 2007, 14, 289-300.

32. Duan, H.D.; Wang; Li, Y. Chem. Soc. Rev. 2015, 44, 5778.

33. Mukherjee, S.; Patra, C.R. Future Sci. 2017, 3, FSO203.

34. Rao, K.; Aziz, S.; Roome, T.; _Razzak, A.; Sikandar, B.; Jamali, K.S.; Imran, M.; Jabri, T.; Shah, M.R. Artif. Cells Nanomed. Biotechnol. 2018. DOI: https://doi.org/10.1080/21691401.2018.1431653.

35. Singh, R.; Lillard, Jr J.W. Exp. Mol. Pathol. 2009, 86, 215-223.

36. Wang, Z.; Zhao, J.; Li, F.; Gao, D.; Xing, B. Chemosphere. 2009,77, 67-73. 